\title{
The Offensive Framework of Resource Based View (RBV): Inhibiting Others from Pursuing Their Own Values
}

\author{
Dr. Seung Hoon Jang \\ Bloomsburg University of Pennsylvania \\ 327 Sutliff Hall, College of Business, East 2nd Street, Bloomsburg, PA, USA \\ E-mail: sjang@bloomu.edu
}

Received: January 28, 2013

Accepted: February 8, 2013

Online Published: February 15, 2013

doi:10.5430/jms.v4n1p62

URL: http://dx.doi.org/10.5430/jms.v4n1p62

\begin{abstract}
This study explores the overlooked aspect of resource based view (RBV). Given the assumption that the relative superiority of resources determines the results of competition, firms are expected to retain sustainable competitive advantage by inhibiting the value creation of other competitors from their resources. The offensive framework of RBV explains how to maintain such a state over other market participants. Based on the theoretical perspectives, including micro-foundation of resources, several propositions are provided concerning this issue. First of all, firms inhibit competitors from acquiring and retaining talent. In addition, firms' innovation activities lower the value of competitors' resources. Finally, firms utilize their resources to inhibit competitors' profit realization, resulting in their competitive advantage. The implications for both academia and industry are discussed, while future research directions are suggested. Firms are recommended to be considered as aggressive warriors as well as farmers or manufacturers.
\end{abstract}

Keywords: RBV, Competitive advantage, Value creation

\section{Introduction}

Firm resource has been an important research topic in the organizational and management field. Penrose (1959) initially recognized the internal resource as the indicator of organizational performance. Wernerfelt (1984) focused on the resources as the core of businesses. Particularly, Barney (1991) contributed to the development of RBV toward the fine-grained level. RBV can be differentiated from other theoretical disciplines like neoclassical and evolutionary economics (Barney, 2001a; Barney, 2001b; Barney, Ketchen, \& Wright, 2011). It is beyond doubt that the achievement and management of resources have been the integral part of business organizations and their activities.

Traditionally, scholars in this research stream have focused on how firms accumulate and utilize their value to create their own value. Several studies have explored the acquisition of firm resources under various contexts like foreign direct investment (FDI) (Hooley, Cox, Shipley, Fahy, Beracs, \& Kolos, 1996), technology-based businesses (Yli-Renko, Autio, \& Sapienza, 2001), entrepreneurial firms (Leung, Zhang, Wong, \& Foo, 2006), small businesses (Winborg \& Landström, 2001), and inter-organizational networks (Wever, Martens, \& Vandenbempt, 2005). In addition, the value creation from firm resources has been investigated by strategy and organization scholars in accordance with topics, including social capital (Tsai \& Ghoshal, 1998), e-business (Amit \& Zott, 2001), organizational learning (Kang, Morris, \& Snell, 2007), and professional service firms (Løwendahl, Revang, \& Fosstenløkken, 2001). For conventional researchers, firms are considered as farmers or manufacturers creating certain types of products or services, resulting in their competitive advantage.

When considering the role of resource differences in explaining the result of competition, it seems likely that firms can retain their competitive advantage based on the "relative" superiority of resource. On one hand, they create own value to retain competitive advantage as the literature proposes. On the other hand, they can hinder competitors from generating their value as the Air Force uses strategic bombing to destroy the enemy's aircraft factories. Therefore, both business firms and the military can continue their lead in resource accumulation, leading to successful competition. Few researchers, however, have explored how firms utilize this alternative method to achieve better resource and competitive advantage. 
This study makes advances in providing this offensive framework of RBV to the management and organization field. The objective of this study is exploring the process of how and why firms inhibit in order to broaden our understating in strategic management now-a-days. For this purpose, major studies in institutionalization and relevant areas are reviewed. And then, the above literature streams are used to provide theoretical propositions that depict how firms emit isomorphic pressures to enhance their competitive advantage. At last, the implications of this viewpoint and future research directions are discussed.

\section{Resource Based View (RBV)}

Increasingly, strategy and organization scholars have employed RBV to figure out various managerial phenomena. Firm resources have shown to play a key role in explaining diverse topics, including general strategic management (Barney, 2001a; Barney, 2001b), strategic alliance (Eisenhardt \& Schoonhoven, 1996; Wassmer \& Dussauge, 2012), corporate diversification (Silverman, 1999), new-product development (Henard \& McFadyen, 2012; Verona, 1999), interfirm cooperation (Combs, 1999), marketing (Srivastava, Fahey, \& Christensen, 2001), international management of small businesses (Westhead, Wright, \& Ucbasaran, 2001), entrepreneurship (Zahra, Hayton, \& Salvato, 2004), and firm innovation (Galunic \& Rodan, 1998). It is obvious from the above literature that the application of resource perspective is the essential part in investigating major research questions in this field.

One of major research questions of RBV is how to gain sustainable competitive advantage. Scholars have focused on the resource characteristics which contribute to the superior position of the firm among competitors. Dierickx and Cool (1989) provided that firm specific resources may be required to implement a strategy successfully. Barney (1991) suggested that a firm may retain competitive advantage for a long time when its resources are valuable, not common, inimitable, and hard to be transferred. Black and Boal (1994) focused on the characteristics of resource-creating processes in which these resource traits are formed. Firm resources have shown to explain overall organizational performance (Ray, Barney, \& Muhanna, 2004). Peteraf (1993) provided that resource heterogeneity plays a key role in competitive advantage and firm performance. Oliver (1997) suggested that firms achieve sustainable competitive advantage by managing the contexts of resource selection. Traditionally, many of the studies regarding this topic have been based on the implicit assumption that firms utilize their resources to improve and create their value.

However, firms can exert negative as well as positive influences toward their surrounding contexts. Martin (2007) and fellow scholars have explored the role of home country on the firm decision to offer a bribe. Environmental side effects of management decisions have been investigated by many researchers (Freedman \& Jaggi, 1982; King \& Lenox, 2002; Lee, 1975). The above literature implies that firms can behave selfish to benefit themselves. Following this notion, the mechanism of how firms enhance competitive advantage by controlling others will be investigated in the next section.

\section{Offensive Framework of RBV}

The literature in this research stream implies that firms are more likely to enhance competitive advantage when they retain the superiority of resources. Resource heterogeneity has shown to play a critical role in understanding the variance of competitive advantage among firms (Barney, 1991; Peteraf, 1993; Wright, McMahan, \& McWilliams, 1994). As scholars like Barney (1991) proposed, it is for sure that firms with valuable, scarce, nontransferable, and inimitable resources are more likely to beat competitors. The question lies in how and why firms outrun the competition from the resource perspectives.

RBV scholars have explored how firms accumulate and utilize resources, leading to the creation of additional value. For a long time, there have been discussions on firms' effort to collect and retain resources. Several studies focused on the dynamic nature of resource formation (Eisenhardt \& Martin, 2000; Teece, 2007; Teece, Pisano, \& Shuen, 1997; Winter, 2003). In addition, firm resources have shown to account for value added in the form of sustainable competitive advantage (Barney, 1991; Oliver, 1997; Peteraf, 1993; Ray, Barney, \& Muhanna, 2004), innovation (Hadjimanolis, 2000; Lawson \& Samson, 2001; Tarafdar \& Gordon, 2007), inter-organizational collaboration (Mowery, Oxley, \& Silverman, 1998), and manufacturing performance (Schroeder, Bates, \& Junttila, 2002).

Given the assumption that "relative" resource heterogeneity explains the firm's competitive advantage, an alternative explanation for this issue is to inhibit competitors from obtaining or utilizing valuable resources. Oliver (1997) proposed that organizations have difficulty in resource acquisition under certain types of restraints, including regulations or the transfer of HR. If firms succeed to exploit these influences, competitors may have difficulty in acquiring resources. Therefore, firms maintain better resources, resulting in the superior position in the competition as can be seen in the Figure 1. The mechanism of how to achieve such a state will be unveiled in the next section. 


\subsection{Micro-Foundation of Resources}

Increasingly, organizational scholars have investigated the micro-foundations of firm resources as the source of competitive advantage (Barney, Ketchen, \& Wright, 2011; Fellin \& Foss, 2005; Foss, 2011; Lippman \& Rumelt, 2003; Minbaeva, Foss, \& Snell, 2009). When considering the history of other social science, RBV scholars need to explore the micro perspective in order to develop RBV as a theoretical tradition (Foss, 2011). Particularly, human resource has been considered as one of major indicators creating organizational value from the micro perspective. Individual employees are the integral parts of organizations (Fellin \& Foss, 2005). Increasingly, RBV and strategic human resource management (SHRM) began to converge each other (Wright, Dunford, \& Snell, 2001). The motivation of human resource has shown to be an integral part of this research stream (Foss, 2010).

Conventional studies regarding this issue have focused on how firms utilize their people to achieve competitive advantage, resulting in better performance. HR has shown to account for sustainable competitive advantage of the firms (Wright, McMahan, \& Abagail, 1994) through various routes, including HR system (Lado \& Wilson, 1994), management of people (Pfeffer, Hatano, \& Santalainen, 1995), human capital (Hatch \& Dyer, 2004), and organizational learning (Pucik, 1988). What all these studies imply is that strategies utilizing the micro-foundation, including HR, have contributed to increase organizational value.

Firms, however, can achieve relative superiority by inhibiting competitors from attracting or retaining of talent. Gardner (2005) provided that rivals compete to hire competent employees. Particularly, the literature on non-compete agreement opens possibilities that firms inhibit competitors from accumulating the micro-foundation of resources. Non-compete agreement refers to "covenants, which constrain the rights to practice one's occupation in competition with the employer after employment has cease (Eslund, 2006, p381)". Non-compete agreement restrains employee mobility to move to other firms (Marx, Strumsky, \& Fleming, 2009; Samila \& Sorenson, 2011). The success of checking competitors from attracting and retaining talent enables firms to accumulate better resources.

Intra-organizational resource, including HR, has long been considered as the source of organizational capabilities to compete (Barney, 1991; Peteraf, 1993; Wright, McMahan, \& McWilliams, 1994). The resource superiority can be obtained through the hindrances to the HR attraction and retention activities by others. Therefore, the enhanced relative position of a firm from the resource perspective is expected to lead to its competitive advantage.

Proposition 1 Firms inhibit competitors from accumulating the micro-foundation of resource, resulting in their competitive advantage.

\subsection{Innovation and Competitors' Resources}

Researchers in the strategy and organization field have explored innovative activities as the sources of value creation in accordance with various topics, including open innovation (Chesbrough, 2003), convergenomics (Lee \& Olson, 2010; Lee, Olson, \& Trimi, 2010), industry architectures (Jacobides, Knudsen, \& Augier, 2006), social capital (Tsai \& Ghoshal, 1998), and buyer-seller relation (Walter, Ritter, \& Gemünden, 2001). The above literature implies that innovation and its results are accountable for a significant portion of value added from modern corporations.

Innovative activities of the firms have shown to play a key role in understanding competitive advantage. Baldridge and Burnham (1975) provided that competitiveness and performance of a firm can be explained by innovation. Narayanan (2001) explored the integrated framework for managing technological innovation to enhance organizational capabilities to compete. Scholars in this research stream have focused on how firms increase their value by participating in innovative processes. Competitive superiority can be achieved when the added value is utilized. For example, the development of new product can change the result of competition.

However, it seems likely that innovation not only leads to the generation of own value but lower the value of competitors' resources. Breakthrough has been considered as one of major characteristics of innovative activities (Herstatt \& Kalogerakis, 2005; Mascitelli, 2000; O'Connor \& Rice, 2001). It allows the creation of products which have not existed before. This fact opens the possibilities that competitors lose strengths in the traditional products. The advent of LCD and PDP TV lowered the value of conventional Braun tube televisions. Furthermore, the resources used for the existing products (e.g. supplies or facilities) may turn into inventory without value. Initiators of innovation can expect the extinction of existing rights, including related resources. Therefore, they are more likely to lead competitors in the value of internal resource.

Resulting resource superiority is accountable for sustainable competitive advantage of the firms. Firms with better resources are more likely to achieve capabilities to compete successfully (Barney, 1991; Barney, 1995; Fahy, 2002). It seems likely that manufacturers of new LCD TVs will beat those with traditional ones. Therefore, competitive superiority is expected to be achieved by lowering the value of competitors' resources through innovative activities. 
Proposition 2 Firms' innovation activities lower the value of competitors' resources, leading to their competitive advantage.

\subsection{Competitors' Profit Realization}

Market has shown to play an essential role in explaining the value creation of firms. Scholars have provided that the market focus of businesses influences on their performances (Hassan, 2012; Narver \& Slater, 1990). Rayport and Sviokla (1995) recommended that managers should focus on market dynamics to create value with intellectual resource. The products or services originated from organizational resources are needed to be launched to the market to realize value. Otherwise, firms have difficulty in achieving expected performance. For this purpose, U.S. responded to the Japanese exporters with the antitrust law and other regulations (Cooper, 2010; Rossman, 1984).

From this perspective, firm resources can be used to control other companies and their business activities rather than create own value. Salop (1979) distinguished two types of entry barriers: innocent and strategic entry barrier. In contrast to the former, the latter is intentionally designed to inhibit the market penetration of others. For instance, intended bans on sales of products may cause the loss of manufacturers. It seems likely that these deliberate hindrances to market entry are the parts of lowering the value of competitors based on own resources.

Particularly, the rights on intellectual capital, including patents, can block the sale of competitors' products. The violation of a copyright act may result in various types of restrictions, including bans on products (Waelde, 2001), and advertising restrictions (Clark, 2007). Since such hindrances restrain firms from accessing the market, they have difficulty in generating financial gains from their resources. Firms can take advantage of this fact to inhibit competitors from creating value based on their resources. The ongoing lawsuits between Apple and Samsung on the disputes over copyrights are good examples of such efforts. Therefore, firms are expected to gain competitive advantage from inhibition to the revenue realization of competitors.

Proposition 3 Firms utilize their resources to inhibit competitors' profit realization, resulting in their competitive advantage.

\section{Discussion \& Implications}

In this study, authors investigated the overlooked aspect of RBV. In contrast to conventional studies, firms are no longer considered as just farmers or manufacturers working for own outputs. Rather, they are also warriors, shrewd tacticians, and strategists attacking their enemies through hindrances to others' HR retention and value creation, and innovative activities destroying the value of competitors' resources. These are alternative ways through which these firms can obtain competitive advantage. Figure 2 describes this offensive framework of RBV.

The implications of this study are clear. First of all, authors contribute to extend the horizon of RBV by providing an additional viewpoint. RBV strategists are expected to pay attention to how to inhibit others to compete successfully. In addition, important strategic implication on resource is provided. Certain types of resources like copyrights can be considered as defensive weapons in possible legal disputes. Firms are recommended to consider this aspect when they make a decision on the purchase of intellectual property rights.

Future scholars are required to pay attention to the other side of RBV and competition among firms. The recommended research directions can serve to guide interested strategy and organization researchers. First, the benefit and cost of the hindrances to competitors needs to be investigated. This evaluation can guide managers to make a right decision on how to utilize their resource. Second, how to protect firms from such hindrances is another interesting topic for scholars. Explicit or implicit declaration of firms' capacities for revenge can be one way to disable willingness to inhibit them. Firms are less likely to be challenged when they can retaliate with more patents.

\section{Conclusion}

Firms as participants of fierce competition have two faces. It is beyond doubt that they can employ both offensive and defensive methods to compete successfully. Since conventional studies have mainly focused on the bright side, researchers now-a-days are required to investigate the other side of competition. Therefore, both researchers and practitioners can access to the reality of competition. Although this perspective does not describe the ideal human nature, it reflects humanity itself. Business is war.

\section{References}

Amit, R., \& Zott, C. (2001). Value creation in E-business. Strategic Management Journal, 22, 493-520. http://dx.doi.org/10.1002/smj.187

Baldridge, J., \& Burnham, R. (1975). Organizational innovation: Individual, organizational, and environmental 
impacts. Administrative Science Quarterly, 20, 165-176. http://dx.doi.org/10.2307/2391692

Barney, J. (1991). Firm resources and sustained competitive advantage. Journal of Management, 17, 99-120. http://dx.doi.org/10.1177/014920639101700108

Barney, J. (1995). Looking inside for competitive advantage. Academy of Management Executive, 9, 49-61.

Barney, J. (2001a). Resource-based theories of competitive advantage: A ten-year retrospective on the resource-based view. Journal of Management, 27, 643-650. http://dx.doi.org/10.1177/014920630102700602

Barney, J. (2001b). Is the resource-based "view" a useful perspective for strategic management research? Yes. Academy of Management Review, 26, 41-56.

Barney, J., Ketchen, D., Jr., \& Wright, M. (2011). The future of resource-based theory: Revitalization or decline? Journal of Management, 37, 1299-1315. http://dx.doi.org/10.1177/0149206310391805

Black, J. A., \& Boal, K. B. (1994). Strategic resources: Traits, configurations and paths to sustainable competitive advantage. Strategic Management Journal, 15, 131-148. http://dx.doi.org/10.1002/smj.4250151009

Chesbrough, H. (2003). Open Innovation: The new imperative for creating and profiting from technology. Boston, MA: Harvard Business School Publishing.

Clark, C. R. (2007). Advertising restrictions and competition in the Children's breakfast cereal industry. Journal of Law and Economics, 50, 757-780. http://dx.doi.org/10.1086/519820

Combs, J. G. (1999). Explaining interfirm cooperation and performance: Toward a reconciliation of predictions from the resource-based view and organizational economics. Strategic Management Journal, 20, 867-888. http://dx.doi.org/10.1002/(SICI)1097-0266(199909)20:9<867::AID-SMJ55>3.0.CO;2-6

Cooper, W. H. (2010, March). US-JAPAN economic relations: Significance, prospects, and policy options. Library of Congress Congressional Research Service. Available: http://www.dtic.mil/cgi-bin/GetTRDoc?AD=ADA516013

Dierickx, I., \& Cool, K. (1989). Asset stock accumulation and sustainability of competitive advantage. Management Science, 35, 1504-1511. http://dx.doi.org/10.1287/mnsc.35.12.1504

Eisenhardt, K. M., \& Martin, J. (2000). Dynamic capabilities: What are they? Strategic Management Journal, 21, 1105-1122. http://dx.doi.org/10.1002/1097-0266(200010/11)21:10/11<1105::AID-SMJ133>3.0.CO;2-E

Eisenhardt, K. M., \& Schoonhoven, C. B. (1996). Resource-based view of strategic alliance formation: Strategic and social effects in entrepreneurial firms. Organization Science, 7, 136-150. http://dx.doi.org/10.1287/orsc.7.2.136

Eslund, C. L. (2006). Between rights and contract: Arbitration agreements and non-compete covenants as a hybrid form of employment law. University of Pennsylvania Law Review, 155, 379-445. http://dx.doi.org/10.2307/40041310

Fahy, J. (2002). A resource-based analysis of sustainable competitive advantage in a global environment. International Business Review, 11, 57-77. http://dx.doi.org/10.1016/S0969-5931(01)00047-6

Fellin, T., \& Foss, N. J. (2005). Strategic organization: A field in search of micro-foundations. Strategic Organization, 3, 441-455. http://dx.doi.org/10.1177/1476127005055796

Foss, N. J. (2011). Why micro-foundations for resource-based theory are needed and what they may look like. Journal of Management, 37, 1413-1428. http://dx.doi.org/10.1177/0149206310390218

Freedman, M., \& Jaggi, B. (1982). Pollution disclosures, pollution performance and economic performance. Omega, 10, 167-176. http://dx.doi.org/10.1016/0305-0483(82)90051-2

Galunic, C., \& Rodan, S. (1998). Resource recombination in the firm: Knowledge structures and the potential for Schumpeterian innovation. Strategic Management Journal, 19, 1193-1201. http://dx.doi.org/10.1002/(SICI)1097-0266(1998120)19:12<1193::AID-SMJ5>3.0.CO;2-F

Gardner, T. M. (2005). Interfirm competition for human resources: Evidence from the software industry. Academy of Management Journal, 48, 237-256. http://dx.doi.org/10.5465/AMJ.2005.16928398

Hadjimanolis, A. (2000). A resource-based view of innovativeness in small firms. Technology Analysis \& Strategic Management, 12, 263-281. http://dx.doi.org/10.1080/713698465

Hassan, A. R. (2012). Market orientation practices of multinationals in Lagos, Nigeria. International Journal of Marketing Studies, 4, 139-149. http://dx.doi.org/10.5539/ijms.v4n5p139 
Hatch, N. W., \& Dyer, J. H. (2004). Human capital and learning as a source of sustainable competitive advantage. Strategic Management Journal, 25, 1155-1178. http://dx.doi.org/10.1002/smj.421

Henard, D., \& McFadyen, M. (2012). Resource dedication and new product performance: A resource-based view. Journal of Product Innovation Management, 29, 193-204. http://dx.doi.org/10.1111/j.1540-5885.2011.00889.x

Herstatt, C., \& Kalogerakis, K. (2005). How to use analogies for breakthrough innovations. International Journal of Innovation and Technology Management, 2, 331-347. http://dx.doi.org/10.1142/S0219877005000538

Hooley, G., Cox, T., Shipley, D., Fahy, J., Beracs, J., \& Kolos, K. (1996). Foreign direct investment in Hungary: Resource acquisition and domestic competitive advantage. Journal of International Business Studies, 27, 683-709. http://dx.doi.org/10.1057/palgrave.jibs.8490149

Jacobides, M. G., Knudsen, T., \& Augier, M. (2006). Benefiting from innovation: Value creation, value appropriation and the role of industry architecture. Research Policy, 35, 1200-1221. http://dx.doi.org/10.1016/j.respol.2006.09.005

Kang, S-. C., Morris, S. S., \& Snell, S. A. (2007). Relational archetypes, organizational learning, and value creation: Extending the human resource architecture. Academy of Management Review, 32, 236-256. http://dx.doi.org/10.5465/AMR.2007.23464060

King, A., \& Lenox, M. (2002). Exploring the locus of profitable pollution reduction. Management Science, 48, 289-299. http://dx.doi.org/10.1287/mnsc.48.2.289.258

Lado, A. A., \& Wilson, M. C. (1994). Human resource systems and sustained competitive advantage: A competency-based perspective. Academy of Management Review, 19, 699-727.

Lawson, B., \& Samson, D. (2001). Developing innovation capability in organizations: A dynamic capabilities. International Journal of Innovation Management, 5, 377-400. http://dx.doi.org/10.1142/S1363919601000427

Lee, D. R. (1975). Efficiency of pollution taxation and market structure. Journal of Environmental Economics and Management, 2, 69-72. http://dx.doi.org/10.1016/0095-0696(75)90022-4

Lee, S. M., \& Olson, D. L. (2010). Convergenomics: Strategic Innovation in the Convergence Era. Burlington, VT: Gower Publishing.

Lee, S. M., Olson, D. L., \& Trimi, S. (2010). Strategic innovation in the convergence era. International Journal of Management and Enterprise Development, 9, 1-12. http://dx.doi.org/10.1504/IJMED.2010.035304

Leung, A., Zhang, J., Wong, P. K., \& Foo, M. D. (2006). The use of networks in human resource acquisition for entrepreneurial firms: Multiple "fit" considerations. Journal of Business Venturing, 21, 664-686. http://dx.doi.org/10.1016/j.jbusvent.2005.04.010

Lippman, S. A., \& Rumelt, R. P. (2003). The payments perspective: Micro-foundations of resource analysis. Strategic Management Journal, 24, 903-927. http://dx.doi.org/10.1002/smj.346

Løwendahl, B. R., Revang, Ø., \& Fosstenløkken, S. M. (2001). Knowledge and value creation in professional service firms: A framework for analysis. Human Relations, 54, 911-931. http://dx.doi.org/10.1177/0018726701547006

Martin, K. D., Cullen, J. B., Johnson, J. L., \& Parboteeah, K . P. (2007). Deciding to bribe: A cross-level analysis of firm and home country influences on bribery activity. Academy of Management Journal, 50, 1401-1422. http://dx.doi.org/10.5465/AMJ.2007.28179462

Marx, M., Strumsky, D., \& Fleming, L. (2009). Mobility, skills, and the Michigan non-compete experiment. Management Science, 55, 875-889. http://dx.doi.org/10.1287/mnsc. 1080.0985

Mascitelli, R. (2000). From experience: Harnessing tacit knowledge to achieve breakthrough innovation. Journal of Product Innovation Management, 17, 179-193. http://dx.doi.org/10.1016/S0737-6782(00)00038-2

Minbaeva, D., Foss, N., \& Snell, S. (2009). Bringing the knowledge perspective into HRM. Human Resource Management, 4, 477-483. http://dx.doi.org/10.1002/hrm.20303

Mowery, D. C., Oxley, J. E., \& Silverman, B. S. (1998). Technological overlap and interfirm cooperation: Implications for the resource-based view of the firm. Research Policy, 27, 507-523. http://dx.doi.org/10.1016/S0048-7333(98)00066-3

Narayanan, V. K. (2001). Managing technology and innovation for competitive advantage. Upper Saddle River, NJ: Prentice Hall.

Narver, J. C., \& Slater, S. F. (1990). The effect of a market orientation on business profitability. Journal of Marketing, 
54, 20-35. http://dx.doi.org/10.2307/1251757

O'Connor, G. C., \& Rice, M. P. (2001). Opportunity recognition and breakthrough innovation in large established firms. California Management Review, 43, 95-116. http://dx.doi.org/10.2307/41166077

Oliver, C. (1997). Sustainable competitive advantage: Combining institutional and resource-based view. Strategic $\begin{array}{llcl}\text { Management } & \text { Journal, } & 18, & \text { 697-713. }\end{array}$ http://dx.doi.org/10.1002/(SICI)1097-0266(199710)18:9<697::AID-SMJ909>3.0.CO;2-C

Penrose, E. T. (1959). The theory of the growth of the firm. New York: John Wiley.

Peteraf, M. A. (1993). The cornerstones of competitive advantage: A resource-based view. Strategic Management Journal, 14, 179-191. http://dx.doi.org/10.1002/smj.4250140303

Pfeffer, J., Hatano, T., \& Santalainen, T. (1995). Producing sustainable competitive advantage through the effective management of people. Academy of Management Executive, 9, 55-72.

Pucik, V. (1988). Strategic alliances, organizational learning, and competitive advantage: The HRM agenda. Human Resource Management, 27, 77-93. http://dx.doi.org/10.1002/hrm.3930270105

Ray, G., Barney, J. B., \& Muhanna, W. A. (2004). Capabilities, business processes, and competitive advantage: Choosing the dependent variable in empirical tests of the resource-based view. Strategic Management Journal, 25, 23-37. http://dx.doi.org/10.1002/smj.366

Rayport, J. F., \& Sviokla, J. J. (1995). Exploiting the virtual value chain. Harvard Business Review, November-December, 75-85.

Rossman, M. L. (1984). Export trading company legislation: U.S. response to Japanese foreign market penetration. Journal of Small Business Management, 22, 62-66.

Salop, S. C. (1979). Strategic entry deterrence. American Economic Review, 69, 335-338.

Samila, S., \& Sorenson, O. (2011). Noncompete covenants: Incentives to innovate or impediments to growth. Management Science, 57, 425-438. http://dx.doi.org/10.1287/mnsc. 1100.1280

Schroeder, R. G., Bates, K. A., \& Junttila, M. A. (2011). A resource-based view of manufacturing strategy and the relationship to manufacturing performance. Strategic Management Journal, 23, 105-117. http://dx.doi.org/10.1002/smj.213

Silverman, B. S. (1999). Technological resources and the direction of corporate diversification: Toward an integration of the resource-based view and transaction cost economics. Management Science, 45, 1109-1124.

Srivastava, R. K., Fahey, L., \& Christensen, H. K. (2001). The resource-based view and marketing: The role of market-based assets in gaining competitive advantage. Journal of Management, 27, 777-802.

Tarafdar, M., \& Gordon, S. R. (2007). Understanding the influence of information systems competencies on process innovation: A resource-based view. Journal of Strategic Information Systems, 16, 353-392.

Teece, D. (2007). Explicating dynamic capabilities: The nature and microfoundations of (sustainable) enterprise performance. Strategic Management Journal, 28, 1319-1350. http://dx.doi.org/10.1002/smj.640

Teece, D., Pisano, G., \& Shuen, A. (1997). Dynamic capabilities and strategic management. Strategic Management Journal, 18, 509-533. http://dx.doi.org/10.1002/(SICI)1097-0266(199708)18:7<509::AID-SMJ882>3.0.CO;2-Z

Tsai, W., \& Ghoshal, S. (1998). Social capital and value creation: The role of intrafirm networks. Academy of Management Journal, 41, 464-476. http://dx.doi.org/10.2307/257085

Verona, G. (1999). A resource-based view of product development. Academy of Management Review, 24, 132-142.

Waelde, C. (2001). The quest for access in the digital era: Copyright and the internet. Journal of Information, Law and Technology, 1. [Online] Available: http://www2.warwick.ac.uk/fac/soc/law/elj/jilt/2001_1/waelde/

Walter, A., Ritter, T., \& Gemünden, H. G. (2001). Value creation in buyer-seller relationships: Theoretical considerations and empirical results from a supplier's perspective. Industrial Marketing Management, 30, 365-377.

Wassmer, U., \& Dussauge, P. (2012). Network resource stocks and flows: How do alliance portfolios affect the value of new alliance formations? Strategic Management Journal, 33, 871-883. http://dx.doi.org/10.1002/smj.973

Wernerfelt, B. (1984). A resource-based view of the firm. Strategic Management Journal, 5, 171-180.

Westhead, P., Wright, M., \& Ucbasaran, D. (2001). The internalization of new and small firms: A resource-based 
view. Journal of Business Venturing, 16, 333-358. http://dx.doi.org/10.1016/S0883-9026(99)00063-4

Wever, S. D., Martens, R., \& Vandenbempt, K. (2005). The impact of trust on strategic resource acquisition through interorganizational networks: Towards a conceptual model. Human Relations, 58, 1523-1543.

Winborg, J., \& Landström, H. (2001). Financial bootstrapping in small businesses: Examining small business managers' resource acquisition behaviors. Journal of Business Venturing, 16, 235-254.

Winter, S. G. (2003). Understanding dynamic capabilities. Strategic Management Journal, 24, 991-995.

Wright, P. M., Dunford, B. B., \& Snell, S. A. (2001). Human resources and the resource based view of the firm. Journal of Management, 27, 701-721. http://dx.doi.org/10.1177/014920630102700607

Wright, P. M., McMahan, G. C., \& Abagail, M. (1994). Human resources and sustainable competitive advantage: A resource-based perspective. International Journal of Human Resource Management, 5, 301-326.

Wright, P. M., McMahan, G. C., \& McWilliams, A. (1994). Human resources and sustained competitive advantage: A resource based perspective. International Journal of Human Resource Management, 5, 301-326.

Yli-Renko, H., Autio, E., \& Sapienza, H. J. (2001). Social capital, knowledge acquisition, and knowledge exploitation in young technology-based firms. Strategic Management Journal, 22, 587-613.

Zahra, S. A., Hayton, J. C., \& Salvato, C. (2004). Entrepreneurship in family vs. non-family firms: A resource-based analysis of the effect of organizational culture. Entrepreneurship Theory and Practice, 28, 363-381.

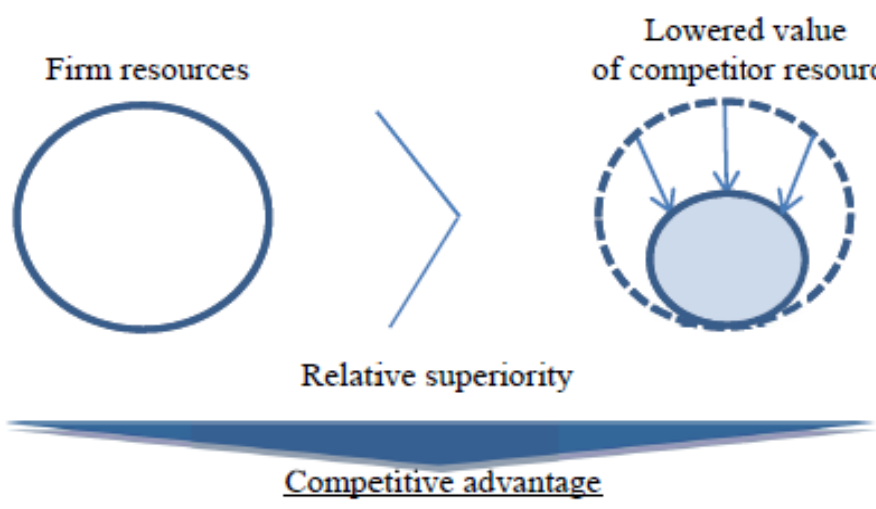

Figure 1. Relative resource superiority and competitive advantage

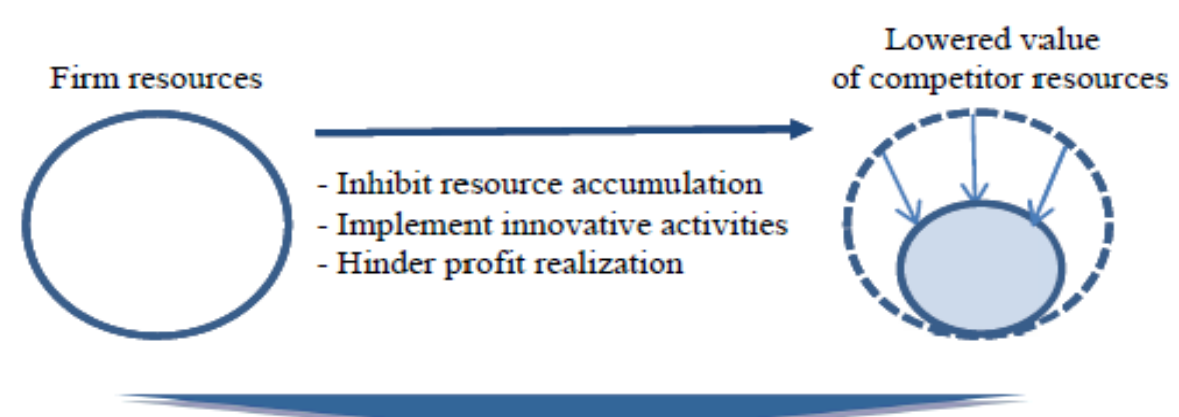

Relative superiority of resources

Competitive advantage

Figure 2. The offensive framework of RBV 